\title{
Testing the Limits of Jurisdiction in Investor-State Arbitration in Svalbard's Waters: Peteris Pildegovics and SIA North Star v. Kingdom of Norway
}

\author{
Valentin J. Schatz ${ }^{\star}$ \\ University of Hamburg, Germany
}

On 1 April 2020, the Latvian fishing company SIA North Star and its owner Peteris Pildegovics initiated an investor-State arbitration against Norway (Peteris Pildegovics and SIA North Star v. Kingdom of Norway) at the International Centre for Settlement of Investment Disputes (ICSID). ${ }^{1}$ This case is not only Norway's first ever ICSID case, ${ }^{2}$ but also the first publicly known investor-State arbitration in which an operator of a fishing vessel has brought a claim against a coastal State for allegedly unlawful exercise of prescriptive and enforcement jurisdiction in relation to fisheries. The case raises intricate questions concerning the limits of jurisdiction ratione materiae and jurisdiction ratione personae of investment tribunals.

These questions concern the relationship between the claimants' arguments and Norway's dispute with the European Union (EU) and some of its Member States (particularly Latvia) ${ }^{3}$ over snow crab in the Barents Sea. This dispute has two distinct legal dimensions. First, it concerns the question of whether the 1920 Spitsbergen Treaty ${ }^{4}$ grants the EU Member States and their vessel operators a right to fish, or a right to be granted licenses to fish, for snow crab on Norway's continental shelf off Svalbard. The second dimension, which is not the focus of this debate article, relates to the question of whether the EU Member States and their vessel operators can rely on the applicable regulations of the North-East Atlantic Fisheries Commission $(\mathrm{NEAFC})^{5}$ to claim a right to fish for snow crab on the continental shelf subjacent to the "Loophole", which is a high seas pocket in the Barents Sea. Given that both aspects of this broader dispute have been the subject of in-depth academic commentary, this debate article will refrain from providing further detail. ${ }^{6}$ Suffice it to note

(C) 2021 Valentin J. Schatz. This is an Open Access article distributed under the terms of the Creative Commons CC-BY 4.0 License. eISSN 2387-4562. https://arcticreview.no.

Citation: Valentin F. Schatz. "Testing the Limits of Furisdiction in Investor-State Arbitration in Svalbard's Waters: Peteris Pildegovics and SIA North Star v. Kingdom of Norway”'Arctic Review on Law and Politics, Vol. 12, 2021, pp. 167-171. http://dx.doi.org/10.23865/arctic.v12.3372 


\section{Valentin F. Schatz}

that the ICSID case is the latest development in the Svalbard "snow crab saga", which has involved proceedings before domestic courts in Norway.

While the dispute remains unresolved on the inter-State level, the claimants, after unsuccessfully exhausting local remedies in relation to enforcement measures taken by Norway in respect of their vessel The Senator, ${ }^{7}$ now seek reparation before an investment tribunal. They invoke the 1992 bilateral investment treaty (BIT) between Latvia and Norway (Latvia-Norway BIT) ${ }^{8}$ as a basis for their claims and the arbitral tribunal's jurisdiction. ${ }^{9}$ Pursuant to Article IX(1) Norway-Latvia BIT, the jurisdiction ratione materiae of arbitral tribunals covers disputes "in relation to an investment" as defined by the BIT. ${ }^{10}$ As some of the claimants' arguments are inextricably linked to the inter-State snow crab dispute, this case has the potential to clarify the limits of jurisdiction ratione materiae and jurisdiction ratione personae of investor-State tribunals. Specifically, it concerns jurisdiction over investment claims that implicate questions of public international law beyond the interpretation and application of the relevant international investment agreement (IIA), particularly with respect to the law of the sea. ${ }^{11}$

A key question in the case is whether, as argued by the claimants, ${ }^{12}$ the licenses to fish for snow crab on Svalbard's continental shelf constitute (parts of) investments protected under the BIT, despite the fact that they were unilaterally issued by Latvia on the basis of EU regulations, ${ }^{13}$ but without Norway's consent. Thus, if these licenses turn out not to be opposable to Norway, the claimants would be responsible for illegal fishing in Norway's waters and would be seeking reparations for suffering enforcement measures as a direct result of that illegal conduct. ${ }^{14}$ That said, if the claimants succeed with their argument that their investment must be viewed "as a whole based on the principle of the unity of the investment", ${ }^{15}$ the jurisdiction with respect to other parts of the investment besides the licenses might more appropriately be challenged with respect to the determinations necessary to decide the claimants' substantive claims.

Article I(1) Norway-Latvia BIT defines "investment" as "every kind of asset invested in the territory of one Contracting Party in accordance with its law and regulations by an investor of the other Contracting Party" (emphasis added). Article IX(1) Norway-Latvia BIT defines "in the territory of" the host State as "including the territorial sea, as well as the continental shelf over which the state concerned exercises, in accordance with international law, sovereign rights for the purpose of exploration and exploitation of natural resources of such areas." ${ }^{16}$ Therefore, the BIT in principle applies to investments pertaining to the exploitation of Norway's continental shelf resources, including sedentary species under Article 77(4) of the United Nations Convention on the Law of the Sea (UNCLOS) ${ }^{17}$ such as the snow crab. However, it is an entirely different question whether the licenses obtained by the claimants qualify as investments made both "in the territory" of Norway ${ }^{18}$ and "in accordance with [Norway's] law and regulations". ${ }^{19}$ As the claimants admit, their line of argument stands and falls with the contested scope of application and the legal consequences 
of the Spitsbergen Treaty's fisheries access provisions. ${ }^{20}$ They allege that Norway violated these provisions by prohibiting the claimants' fishing activities in Svalbard's waters and by taking enforcement measures against the claimants. ${ }^{21}$

Therefore, in order to qualify the Latvian fishing licenses (and related fishing operations) as an "investment" under the Norway-Latvia BIT, the arbitral tribunal would have to decide, as an incidental issue, the inter-State dispute between Latvia and Norway concerning the Spitsbergen Treaty. Do investment tribunals have jurisdiction ratione materiae to take such decisions? While the claimants argue that such a determination "is clearly within [the arbitral tribunal's] jurisdiction and competence", ${ }^{22}$ the matter is far from clear. Indeed, it may be doubted that investment tribunals have jurisdiction ratione materiae to make determinations of breaches of rules of international law not included in the jurisdictional provision(s) of the relevant IIA, particularly where inter-State disputes of political significance are concerned. ${ }^{23}$ In addition, there is a closely connected, and in the context of investor-State arbitration inextricably linked, issue of jurisdiction ratione personae because Latvia and other affected Contracting Parties to the Spitsbergen Treaty are not parties to the proceedings. ${ }^{24}$ Previous investment tribunals have avoided such determinations and indicated in obiter dicta that they would be unable to make prior determinations of breaches of international law other than the provisions of the relevant IIA..$^{25}$

Against this background, a legally binding decision of the snow crab dispute would more appropriately be sought before a judicial or arbitral inter-State dispute settlement body with primary jurisdiction to decide on the interpretation and application of the Spitsbergen Treaty, such as the International Court of Justice. ${ }^{26}$ Such proceedings would also allow other Contracting Parties of the Spitsbergen Treaty to intervene, which would enable them not only to express their views on the matter, but also make the judgment binding upon them. ${ }^{27}$ It remains to be seen whether the arbitral tribunal in Peteris Pildegovics and SIA North Star v. Kingdom of Norway, which comprises pre-eminent public international law experts, will adopt a conservative or an expansive approach to its jurisdiction. At the time of writing, Norway had indicated that it intends to contest the arbitral tribunal's jurisdiction, but had not requested a bifurcation of the proceedings into preliminary objections and merits stages as "several of its objections are better dealt with together with a thorough discussion of the facts". ${ }^{28}$

\section{NOTES}

* Research Associate and Post-Doctoral Researcher, Institute for the Law of the Sea and Maritime Law, Faculty of Law, University of Hamburg, valentin.schatz@uni-hamburg.de. The author is indebted to Sebastian Wuschka (Research Fellow in Tax Disputes and International Arbitration, University of Lausanne) for his insightful comments on an earlier manuscript.

1. Peteris Pildegovics and SIA North Star v. Kingdom of Norway, Request for Arbitration, 18 March 2020, ICSID Case No. ARB/20/11. 
2. Lisa Bohmer, "Snow Crab Dispute Prompts First ICSID Arbitration Against Norway," Investment Arbitration Reporter (2020), https://www.iareporter.com/articles/snow-crabdispute-prompts-first-icsid-arbitration-against-norway/.

3. Latvia even requested the EU General Court to order the EU Commission to act in this respect. See Republic of Latvia v European Commission (T-293/18), Order of the General Court (Fourth Chamber), 30 January 2020, ECLI:EU:T:2020:29.

4. Treaty relating to Spitsbergen (9 February 1920) The American fournal of International Law 18 (1924): 199.

5. Convention on Future Multilateral Cooperation in North-East Atlantic Fisheries (18 November 1980) 1285 UNTS 129.

6. For discussion, see Harald S. B. Hansen, "Three Major Challenges in Managing NonNative Sedentary Barents Sea Snow Crab (Chionoecetes opilio)," Marine Policy 71 (2016): 38; Andreas Østhagen and Andreas Raspotnik, "Crab! How a Dispute over Snow Crab Became a Diplomatic Headache between Norway and the EU," Marine Policy 98 (2018): 58; Andreas Østhagen and Andreas Raspotnik, "Why Is the European Union Challenging Norway Over Snow Crab? Svalbard, Special Interests, and Arctic Governance," Ocean Development \& International Law 50 (2019): 190; Robert C. Steenkamp, "Svalbard's 'Snow Crab Row' as a Challenge to the Common Fisheries Policy of the European Union," The International Fournal of Marine and Coastal Law 35 (2020): 106; Bernt A. Bertheussen et al., "Fishing for an Institution-based First-mover Advantage: The Norwegian Snow Crab Case," Ocean \& Coastal Management 194 (2020): 105274; Rachel Tiller and Elizabeth Nyman, "The Clear and Present Danger to the Norwegian Sovereignty of the Svalbard Fisheries Protection Zone: Enter the Snow Crab," Ocean E Coastal Management 137 (2017): 24; Øystein Jensen, "The Svalbard Treaty and Norwegian Sovereignty," Arctic Review on Law and Politics 11 (2020): 82.

7. The Supreme Court of Norway - Judgment of 14 February 2019 ref HR-2019-282-S, https://www.domstol.no/globalassets/upload/hret/decisions-in-english-translation/hr-2019282-s.pdf. For commentary, see Tore Henriksen, "The Senator Case: A New Turn in Norway's Dealings with Foreign Vessels Operating in the Waters off Svalbard," The NCLOS Blog (2019), https://site.uit.no/nclos/2019/02/28/the-senator-case-a-new-turn-in-norwaysdealings-with-foreign-vessels-operating-in-the-waters-off-svalbard/; Tore Henriksen, "Snow Crab in the Barents Sea: Managing a Non-native Species in Disputed Waters," Arctic Review on Law and Politics 11 (2020): 108, 111-112. Compare also Peteris Pildegovics and SIA North Star v. Kingdom of Norway, Claimants' Memorial, 11 March 2021, ICSID Case No. ARB/20/11, paras. 368-433 [Claimants' Memorial].

8. Agreement between the Government of the Kingdom of Norway and the Government of the Republic of Latvia on the Mutual Promotion and Protection of Investments (16 June 1992), https://investmentpolicy.unctad.org/international-investment-agreements/treaty-files/1873/ download.

9. Claimants' Memorial (n 7), paras. 436-439.

10. See also Article 25(1) of the Convention on the Settlement of Investment Disputes between States and Nationals of Other States (18 March 1965) 575 UNTS 159.

11. See generally Peter Tzeng, "Investment Protection in Disputed Maritime Areas," Fournal of World Investment \& Trade 19 (2018): 828.

12. Claimants' Memorial (n 7), paras. 519-523.

13. See, e.g., Council Regulation (EU) 2020/123 of 27 January 2020 fixing for 2020 the fishing opportunities for certain fish stocks and groups of fish stocks, applicable in Union waters and, for Union fishing vessels, in certain non-Union waters, Official fournal of the European Union L 25 (2020): 1. 
14. See Para. 3.1.1 of the FAO's International Plan of Action to Prevent, Deter and Eliminate Illegal, Unreported and Unregulated Fishing (2001), http://www.fao.org/fishery/ipoa-iuu/ en: "Illegal fishing refers to activities [...] conducted by national or foreign vessels in waters under the jurisdiction of a State, without the permission of that State, or in contravention of its laws and regulations".

15. Claimants' Memorial (n 7), paras. 478-486.

16. Article II(4) Norway-Latvia BIT.

17. United Nations Convention on the Law of the Sea (10 December 1982) 1833 UNTS 3.

18. Claimants' Memorial (n 7), para. 576.

19. Ibid., paras. 586-589. On this requirement, see Zachary Douglas, "The Plea of Illegality in Investment Treaty Arbitration,” ICSID Review - Foreign Investment Law fournal 29 (2014): 155; Jarrod Hepburn, "In Accordance with Which Host State Laws? Restoring the 'Defence' of Investor Illegality in Investment Arbitration,” Fournal of International Dispute Settlement 5 (2014): 531.

20. Claimants' Memorial (n 7), para. 589.

21. Ibid., para. 630-673.

22. Ibid., para. 589 .

23. Marco Benatar and Valentin J. Schatz, "The Protection of Foreign Investments in Disputed Maritime Areas," in Investments in Conflict Zones: The Role of International Investment Law in Armed Conflicts Disputed Territories, and 'Frozen' Conflicts, eds. Tobias Ackermann and Sebastian Wuschka (Leiden: Brill, 2021), 176-208, 188 and 195. Compare also RSM Production Corp v Grenada, Final Award, 18 March 2009, ICSID Case No. ARB/05/14, para. 333: "ICSID Tribunals are not empowered to delimit maritime boundaries".

24. Peter Tzeng, "Investments on Disputed Territory: Indispensable Parties and Indispensable Issues," Brazilian fournal of International Law 14 (2017): 124; Benatar and Schatz (n 23), 192-195.

25. Peter Tzeng, "The Implicated Issue Problem: Indispensable Issues and Incidental Jurisdiction," New York University fournal of International Law \& Politics 50 (2018): 447, 485-487, with reference to Archer Daniels Midland Co and Tate $\mathcal{E}$ Lyle Ingredients Americas, Inc v Mexico, Award, 21 November 2015, ICSID Case No. ARB(AF)/04/5, para. 133; Corn Products International, Inc v Mexico, Decision on Responsibility, 15 January 2008, ICSID Case No. ARB (AF)/04/1, paras. 181-189.

26. See Valentin J. Schatz, "The Snow Crab Dispute on the Continental Shelf of Svalbard: A Case-Study on Options for the Settlement of International Fisheries Access Disputes," International Community Law Review 22 (2020): 455. On the potential of inter-State investment proceedings in similar cases, see Peter Tzeng, "Sovereignty over Crimea: A Case for State-to-State Investment Arbitration," Yale fournal of International Law 41 (2016): 459.

27. Article 63 of the Statute of the International Court of Justice (26 June 1945), https://www. icj-cij.org/en/statute.

28. Peteris Pildegovics and SIA North Star v. Kingdom of Norway, Request for Bifurcation, 8 April 2021, ICSID Case No. ARB/20/11, para. 2. 